\title{
Seed rain as an ecological indicator of forest restoration in the Pampa biome
}

\author{
Djoney Procknow ${ }^{1} \oplus$, Ana Paula Moreira Rovedder ${ }^{1} \oplus$, Bruna Balestrin Piaia ${ }^{1} \oplus$, Maureen de Moraes Stefanello ${ }^{1} \oplus$,

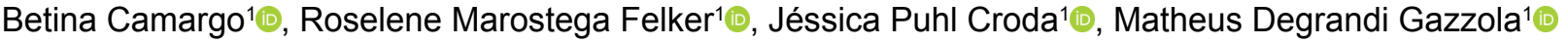

\footnotetext{
1 Universidade Federal de Santa Maria, Santa Maria, RS, Brasil. E-mail: djoneyprocknow@gmail.com; anarovedder@gmail.com; brunabpiaia@gmail.com; mmstefanello@gmail.com; betinacamarg093@gmail.com; marostegafelker@gmail.com; jessica.croda@hotmail.com; matheus.d.gazzola@gmail.com
}

ABSTRACT: This study evaluated seed rain in different forest formation soil uses in the Serra do Sudeste region, Pampa biome. Four area were selected: active restoration (Area 1), passive restoration (Area 2), eucalyptus commercial plantation (Area 3) and native forest (Area 4). Ten permanent collectors of $1 \mathrm{~m}^{2}$ each were installed in each area, being suspended 1 meter above the soil surface. Collections were made monthly for twelve months in 2018. The analyzed variables were: the number of morphospecies, number of individuals, the indices of Margalef richness, Pielou evenness, Shannon diversity, Jaccard floristic similiarity, and possible correlations by detrended correspondence analysis (DCA). Total number of seeds sampled during the period was 239,988 , distributed across 116 morphospecies. The area under active restoration (Area 1) did not differ statistically by the Kruskall-Wallis test $(p<0.05)$ of the native forest (Area 4$)$ for the number of seeds. Area 1 presented a higher number of morphospecies and greater diversity of species, followed by Area 4. Seed rain can be a promising ecological indicator for the conditions of the present study.

Key words: active restoration; diversity; morphospecies; native forest

\section{Chuva de sementes como indicador ecológico de restauração florestal no bioma Pampa}

RESUMO: O presente estudo avaliou a chuva de sementes em diferentes usos do solo de formação florestal na região da Serra do Sudeste, bioma Pampa. Foram selecionadas quatro áreas: restauração ativa (Área 1), restauração passiva (Área 2), plantio comercial de eucalipto (Área 3) e mata nativa (Área 4). Em cada área, foram instalados dez coletores permanentes de $1 \mathrm{~m}^{2}$ cada, suspensos a $1 \mathrm{~m}$ acima da superfície do solo. As coletas foram feitas mensalmente durante doze meses no ano de 2018. As variáveis avaliadas foram: número de morfoespécies, número de indivíduos, riqueza de Margalef, equitabilidade de Pielou, diversidade de Shannon, similiaridade florística de Jaccard e as possíveis correlações pela análise de correspondência segmentada (DCA). $O$ total de sementes amostradas durante o período foi 239.988 , distribuídas em 116 morfoespécies. A área sob restauração ativa (Área 1) não diferiu estatisticamente pelo teste de Kruskall-Wallis $(p<0,05)$ da mata nativa (Área 4), quanto ao número de sementes. A Área 1 apresentou maior número de morfoespécies e maior diversidade de espécies, seguida pela Área 4. A chuva de sementes demonstrou ser um promissor indicador ecológico para as condições do presente estudo.

Palavras-chave: restauração ativa; diversidade; morfoespécies; mata nativa 


\section{Introduction}

The Pampa biome is formed by ecosystems with high species' diversity, thus guaranteeing important environmental services such as the conservation of water resources, the availability of pollinators and the provision of genetic resources (Pillar et al., 2009). The biodiversity of this biome has been threatened by the progressive introduction and expansion of monocultures, pastures with exotic species (Amaral et al., 2016), exotic forest species (Echer et al., 2015), and extensive cattle raising above stocking capacity (Marchi et al., 2018). These factors have been drastically reducing the vegetation cover, resulting in the fragmentation of the biome where the native biota remains isolated on habitat islands separated by degraded landscapes (Marchi et al., 2018).

Some recommendations have been proposed to achieve successful restoration projects in forest physiognomies in the Pampa biome, with the need for research activities and monitoring of determinant processes being necessary for the success of the projects (Rovedder et al., 2017). It is necessary to use variables for the monitoring stage which are technically called ecological indicators (Durigan, 2011). The ideal situation is to find simple indicators which act as representatives of a set of attributes of the ecosystem (Durigan \& Engel, 2015).

One of the ecological indicators for the regeneration capacity and establishment of plant populations is the seed rain, which expresses the natural dynamics of vegetation, and is an indicator of the potential for resilience (Tres et al., 2007). Seed rain can be considered as the set of propagules from the external vegetation (alien) and/or from the area itself (indigenous) (Campos et al., 2009), which reach the areas through different dispersion forms.

Seed rain is an important tool which enables obtaining information on species composition, seed availability and diversity, and is therefore essential for monitoring areas undergoing the restoration process (Piña-Rodrigues \& Aoki, 2014). In view of the above, the objective of the present study was to evaluate seed rain in different forest formation soil uses in the Pampa biome of the Serra do Sudeste region, Brazil.

\section{Materials and Methods}

\section{Study location}

This study was carried outin the municipality of Caçapava do Sul, in the Serra do Sudeste region of the Pampa biome in the State of Rio Grande do Sul (30.21'31.31'S and

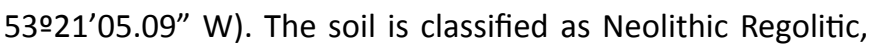
and having a wavy to strong wavy relief associated with rock outcrops (Streck et al., 2008). The region's vegetation is composed of grassland in the mountain ranges and tops, shrublandsin the flat and humid parts, being in connection with savanoid vegetation (vassourais). There are also forest formations with a predominance of Semi-deciduous Seasonal Forest (SSF) with elements of the Mixed Ombrophilous Forest in the areas of higher altitude, smaller forest formations (capões) and riparian forests (Rovedder 2013; Overbeck et al.,
2015; Rovedder et al., 2017; Guarino et al., 2018). The semideciduous character of SSF occurs in Rio Grande do Sul due to the temperature distinction between the seasons, unlike the deciduousness in tropical Brazil which occurs due to the presence of a dry season. The region's climate is Cfa according to the Köppen classification, described ashumid subtropical with hot summers and no defined dry season. The average annual temperature is $18.1^{\circ} \mathrm{C}$ (Alvares et al., 2013).

Four areas were selected on the experimental area, three of which were defined as the Permanent Preservation Area (PPA) (Table 1).

The strategy used in active restoration was planting in nuclei using native forest species. 40 nuclei were planted randomly per hectare with five seedlings per nucleus. The passive restoration site has been isolated by fencing for 12 years after the removal of cattle. Commercial eucalyptus planting is found around the areas. Area 4 consists of a Semideciduous Seasonal Forest fragment. The floristic assessment showed 21 forest species, inwhich Luehea divaricata Mart. \& Zucc., Cordia americana (L.) Gottshling \& J.E.Mill., Eugenia uniflora L., and Chomelia obtusa Cham. \& Schultdl. showed the highest densities. The forest fragment has a border effect along its entire length, with an average width of $150 \mathrm{~m}$ and a length of $1.6 \mathrm{~km}$.

Table 1. Representation, description and characteristics of the study areas in the municipality of Caçapava do Sul, RS, Brazil.

\begin{tabular}{clccc}
\hline \multirow{2}{*}{ Areas } & \multirow{2}{*}{ Treatment } & \multicolumn{3}{c}{ Characteristics } \\
\cline { 3 - 5 } & & Hectares & Age & PPA \\
\hline 1 & Active restoration & 0.5 & 07 years & $\mathrm{x}$ \\
2 & Passive restoration & 0.5 & 12 years & $\mathrm{x}$ \\
3 & Commercial Eucalyptus plantation & 80 & 03 years & - \\
4 & Native forest & 24 & - & $\mathrm{x}$ \\
\hline
\end{tabular}

PPA = permanent preservation area.

\section{Data colletion}

The seed rain was assessed by permanent collectors of $1 \mathrm{~m}^{2}$ each, suspended at $1 \mathrm{~m}$ above the soil surface. The collectors were made using wooden stakes and a $5 \mathrm{~mm}$ mesh sombrite screen. Ten collectors were installed at random in each area in November 2017, with each collector being a repetition. The collectors in Area 1 were allocated below the nuclei.

The collection of deposited material was carried out monthly for a period of 12 months (December 2017 to November 2018). The seeds were separated from the material deposited in the collectors, discarding the rest. All collected seeds were classified by "morphospecies", considering their external morphology (Piña-Rodrigues \& Aoki, 2014).

The seeds were classified by dispersion according to Van der Pijl (1982). They were classified as anemochoric (dispersion by wind), zoochoric (dispersion by animals) and autochoric (dispersion by the mother plant).

\section{Data analysis}

The total amount of seeds sampled in each area was subjected to the Shapiro Wilk and Bartlett tests to verify the normality assumptions of error distribution and homogeneity 
of variances, respectively. As the assumptions were not met, the Kruskall-Wallis non-parametric test was performed ( $p$ $<0.05)$. The analyzes were performed with the $\mathrm{R}$ program (version 3.5) using the Agricolae package.

The seed rain was analyzed from the calculations of Richness (S), and Margalef's richness, Pielou's evenness and Shannon's diversity indices (Müeller-Dombois \& Ellenberg, 1974). The calculated Shannon's diversity index and Pielou's evenness index values of each area were compared using the Hutcheson t-test at the level of $5 \%$ probability $(p<0.05)$ (Hutcheson, 1970), and the values of richness were compared by the Kruskall-Wallis test at the level of $5 \%$ probability $(p<0.05)$.

The similarity between the areas was assessed using the Jaccard index (Müeller-Dombois \& Ellenberg, 1974). The species composition (number of seeds/species) of the seed rain and the dispersion syndrome in each studied area was analyzed by detrended correspondence analysis (DCA). All analyzes were performed using the PAST program version 2.17 (Hammer et al., 2004). Low abundance species (species $<20$ seeds) were removed to avoid noise in the analysis.

\section{Results and Discussion}

The total number of seeds sampled was $239,988(5,999$ seeds $\mathrm{m}^{-2}$ ) distributed in 116 morphospecies. A total of 25 of these were identified at the species level, distributed in 19 botanical families.

Area 2 (Figure 1) presented the largest amount of sampled seeds $(190,249)$, distributed in 31 morphospecies. The most representative specie was Baccharis dracunculifolia DC. with $98.41 \%$ of the sampled seeds.

There was a statistically significant difference $(p<0.05)$ by the Kruskal-Wallis test for the number of seeds collected in the studied areas. Area 1 (active restoration) did not differ statistically from Area 4 (native forest), however Areas 2 (passive restoration) and 3 (commercial eucalyptus plantation) showed a significant difference in the number of seeds collected (Table 2 ).

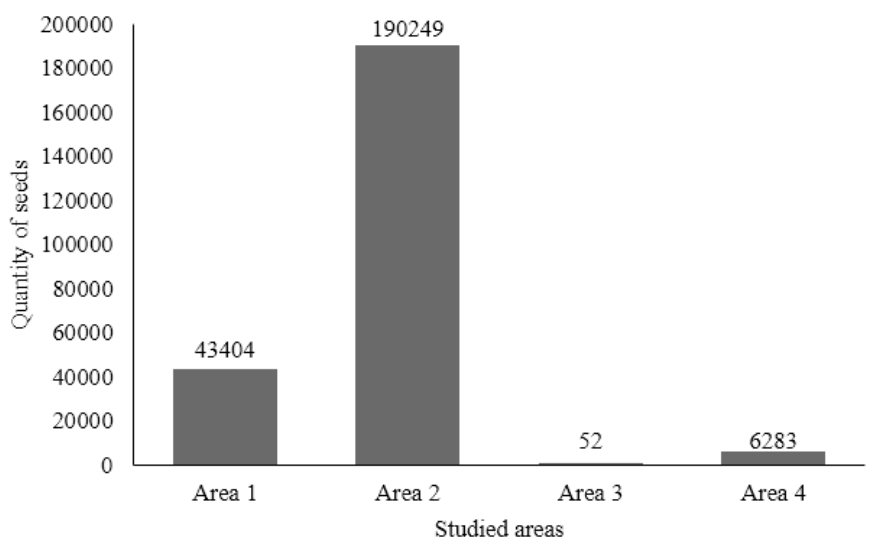

Area 1: planting in nuclei; Area 2: passive restoration area; Area 3: area with eucalyptus plantations; Area 4: native forest.

Figure 1. Quantity of seeds sampled in each study area in the 12-month period.
Table 2. Kruskal-wallis pair comparison test of the number of seeds collected in each study area in the municipality of Caçapava do Sul, RS, Brazil.

\begin{tabular}{cc}
\hline Areas & $X$ of the seeds \\
\hline 1 & $361.7 \mathrm{~b}$ \\
2 & $1585.40 \mathrm{a}$ \\
3 & $0.433 \mathrm{c}$ \\
4 & $52.79 \mathrm{~b}$ \\
\hline
\end{tabular}

Area 1: planting in nuclei; Area 2: passive restoration area; Area 3: area with eucalyptus plantations; Area 4: native forest. Averages followed by the same letter do not differ by the Kruskal-Wallis test at $5 \%$ probability of error.

The significant amount of seeds sampled in Area 2 can be explained by the presence of the $B$. dracunculifolia specie, which presented $98.41 \%$ of the seeds present in the area. The region is known for its mosaic of grassland, shrub and tree formations. Among the shrub formations (also called savanoids), there are "vassourais", with a predominance of Asteraceae, mainly of the Baccharis genus (Rovedder, 2013; Guarino et al., 2018). Due to the expressiveness of $B$. dracunculifolia seeds in A2, we can infer that passive restoration under the study conditions favor the typical ecological succession of the region, which is represented by a prolonged stage of savanoid vegetation with shrubs of heliophilous and anemochoric dispersion species stand out. Ecological succession and the transition between grassland and forest are still process which needs to be better elucidated in the Pampa biome. This transition is a natural process of the biome; the climatic optimum was reached between 4000 and 5000 years BC which culminated in the current more humid climate with well distributed rainfall, leading to the expansion of the Atlantic Forest to the south of Brazil and favors the transition for forest formations (Marchiori, 2006; Rovedder, 2013).

The low number of seeds sampled in Area 3 may be related to the commercial eucalyptus planting. Monodominant areas such as eucalyptus stands or bamboo species massifs are reported as limiting barriers for fauna and seed rain dispersal (Marsden et al., 2001; Bona et al., 2020), the seed bank (Vinha et al., 2017) and natural regeneration (Felker et al., 2018). In addition, the eucalyptus matrix can hinder the circulation of native seeds of anemochorous dispersion, as it also acts as a barrier to wind circulation (Piña-Rodrigues \& Aoki, 2014).

Area 4 presented greater values for ecological indexes, mainly richness (S), Margalef's richness (d) and Shannon's diversity index $\left(\mathrm{H}^{\prime}\right)$ (Table 3 ). This result is consistent with its role as a control of the original ecosystem. Considering that Shannon's diversity $\left(H^{\prime}\right)$ is a relationship between richness and number of individuals (Piña-Rodrigues \& Aoki, 2014), it is possible to understand the low values of this index for the areas with the highest number of seeds collected, namely Areas 1 and 2 .

The fact that Area 3 has one of the highest Shannon diversity indexes is probably related to the lower number of seeds, which may have increased the evenness between species. PiñaRodrigues \& Aoki (2014) found similar results in seed rain in forest fragments. They verify the forest fragment that had less 
Table 3. Species/morphospecies richness (S); Margalef's richness (d); Pielou's evenness ( $\left.\mathrm{J}^{\prime}\right)$ and Shannon's diversity $\left(\mathrm{H}^{\prime}\right)$ for seed rain planted in nuclei (Area 1), passive restoration (Area 2), commercial planting of eucalyptus (Area 3) and native forest (Area 4).

\begin{tabular}{ccccc}
\hline Areas & $\mathrm{S}$ & $\mathrm{d}$ & $\mathrm{J}^{\prime}$ & $\mathrm{H}^{\prime}$ \\
\hline 1 & $67 \mathrm{~b}^{*}$ & 5.99 & $0.1587 \mathrm{c}^{* *}$ & $0.6624 \mathrm{c}^{* *}$ \\
2 & $31 \mathrm{c}$ & 2.46 & $0.0341 \mathrm{~d}$ & $0.1171 \mathrm{~d}$ \\
3 & $14 \mathrm{~d}$ & 3.29 & $0.8584 \mathrm{a}$ & $2.265 \mathrm{~b}$ \\
4 & $79 \mathrm{a}$ & 8.69 & $0.6468 \mathrm{~b}$ & $2.810 \mathrm{a}$ \\
\hline
\end{tabular}

* Values followed by the same letter in the column do not differ by the Kruskal-Wallis test at $5 \%$ probability of error. ${ }^{* *}$ Values followed by the same letter in the column do not differ by the Hutcheson $\mathrm{t}$-test at $5 \%$ probability of error.

richness and less abundance obtained a higher Shannon index. The mathematical reason for this index can lead to erroneous interpretations from an ecological point of view, generating an overestimation of diversity (Magurran, 2013).

In relation to species, Area 1 presented the second highest morphospecies richness (S), however with a low Pielou evenness level $\left(J^{\prime}=0.1587\right)$. Area 2 had the lowest evenness level $\left(J^{\prime}=0.0341\right)$. It indicates that few species concentrate the largest amount of sampled seeds (Piña-Rodrigues \& Aoki, 2014). This factor can be explained by the abundant presence of $B$. dracunculifolia specie in the area.

Area 3 had the highest Pielou evenness index $\left(J^{\prime}=0.8584\right)$. It means a high distribution uniformity of individuals between species, however with a low amount of morphospecies and a low number of seeds.
Kanieski et al. (2017) classified the Margalef index value of 2.20 as low diversity in order to find the best indicators to assess the structure and diversity of the tree component in a Mixed Ombrophilous Forest. The same occurred in the PiñaRodrigues \& Aoki (2014) study. They classified the value of 1.002 found for the Margalef index in a study of seed rain as low species richness. In addition, in another study of the tree component Kanieski et al. (2010) found Margalef index values which ranged from 6.24 for the lowest diversity plot to 10.05 for the highest diversity plot with an average of 8.38, which denotes high diversity in the tree component. Therefore, it can comparatively be concluded that Area 4 presented high species diversity $(d=8.69)$, Area 1 presented medium species diversity $(d=5.993)$, and Areas 2 and 3 showed low species diversity ( $d=2.488$ and 3.29 , respectively).

The anemochoric dispersion syndrome is correlated to a greater degree with Area 2, and it is also correlated to a lesser extent with Areas 1 and 3 . Area 4 is more closely related to the zoochoric dispersion syndrome (Figure 2). A predominance of zoochoric syndrome in subtropical and neotropical forest ecosystems has been widely documented (Budke et al. 2005; Giehl et al. 2007; Scipioni et al., 2013; Sccoti et al., 2016; Capellesso et al., 2018). On the other hand, the relationship between the seed rain composition and the successional stage has produced less consensus even until today.

Huanca Nuñez et al. (2019) did not find an increase in the species percentage of zoochoric syndrome in the seed rain with the increase in the successional age of secondary tropical

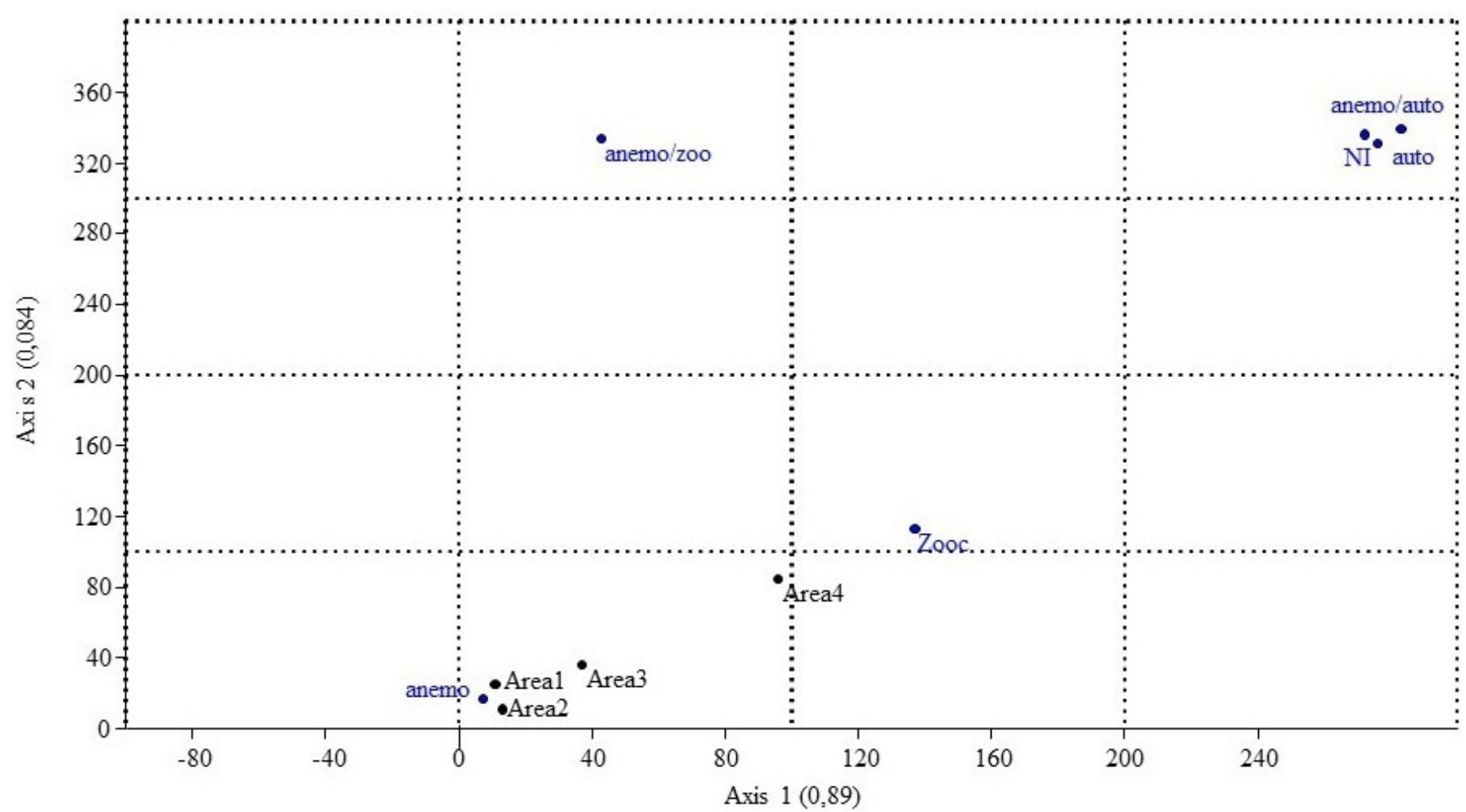

Area 1: planting in nuclei; Area 2: passive restoration area; Area 3: area with eucalyptus plantations; Area 4: native forest.

Figure 2. Corrected correspondence analysis (DCA) for seed rain and seed dispersal syndrome in the municipality of Caçapava do Sul, RS, Brazil. Anemo = anemochorous; Zooc = zoochoric; Auto = Autochoric; Anemo/zoo = Anemochoric and Zoochoric; Anemo/auto = Anemochoric and Autochoric; $\mathrm{NI}=$ Not identified. 
forests, although the species assembly in the seed rain has approached the assembly of mature forests. On the other hand, in evaluating seed rain over nine years, Wang et al. (2019) found $54 \%$ of the propagules belonging to the typical species of mature forests; a percentage which the authors considered low for their study conditions. Due to the heterogeneity and multidirectional nature of ecological succession processes, there is no seed rain pattern, and therefore such results are not self-excluding.

This greater interaction between Area 2 (which has been under passive restoration for 12 years) with the anemochoric dispersion syndrome corroborates the study by Souza et al. (2018), in which two areas with nine years of isolation registered a greater predominance of anemochoric seeds. These results are also similar to the study by Souza et al. (2014). They verify $95 \%$ of the diaspores found in the seed rain in an abandoned agricultural area (with regenerated vegetation without a completely closed canopy) 18 years ago were composed of anemochoric species. The same authors mention that this result is probably related to the absence of a closed canopy.

This interaction can also be explained by the high density of $B$. dracunculifolia seeds belonging to the Asteraceae family. The Baccharis genus indicates the initial character of the restoration process, because these species generally prefer open areas or altered forests where there is greater light incidence (Rech et al., 2015). These species occur in grasslands or in open sites, constituting dense and dominant formations in capoeiras and degraded lands (Araújo et al., 2003). In addition, according to Fagundes et al. (2005), B. dracunculifolia is considered a colonizer of disturbed environments.

Area 1 (planting in nuclei) had a predominance of the anemochoric dispersion syndrome (Figure 2), however, in a less degree level interaction when compared to Area 2 (passive restoration area). Probably due to the easy circulation of seeds between the open spaces around the nuclei even though the nuclei planting technique has been implanted for seven years. We verify the occurrence of $B$. dracunculifolia seeds in Area 1, probably due to its proximity to Area 2; a factor which may have caused this predominance in the amount of anemochoric seeds.

Area 4 has a greater degree of correlation with the zoochoric dispersion syndrome, which can be explained by the fact that the native forest enables maintaining fauna which seeks refuge, food and water, and thus favors this syndrome in this environment (Venzke et al., 2014).

The composition of seed rain species showed similarity by the Jaccard index, varying from 0.15 to 0.35 between the areas studied (Figure 3). It is possible to observe that Areas 1 and 4 had greater similarity when compared to Areas 2 and 3. Area 4 is a native forest, and therefore has its own support in the seed rain. Area 1 is similar to the native forest, possibly due to two aspects: (1) the release of seeds from the trees which were planted in the nuclei; and (2) the nuclei are being effective in their processes, mainly in attracting fauna which are seed dispersers.
The dissimilarity in Area 2 under passive restoration for 12 years can be explained by the expressive amount of $B$. dracunculifolia species. However, the dissimilarity in Area 3 can be explained by the canopy cover of the eucalyptus plantation, it acts as a barrier to the propagules in this area.

In the detrended correspondence analysis (DCA) (Figure $4)$, there is a correlation of the $B$. dracunculifolia species with Area 1 and to a greater degree with Area 2. This correlation can be explained because the species has typical capoeira characteristics (Brack et al., 1998) and finds favorable conditions for its establishment in these two areas. The specie is typical of fields in the Pampa biome (Overbeck et al., 2015) and has its own characteristics of colonizing plants and frequently occurs in disturbed areas and pastures (Gomes \& Fernandes, 2002). B. dracunculifolia belongs to the Asteraceae family, which constitutes the family with the highest specific richness in the State of Rio Grande do Sul, and can form dense populations (Boldrini et al., 2015) in sites which are favorable for their development.

Area 3 mainly correlates with the Moquiniastrum polymorphum, Solanum mauritianum and Vernonia discolor species. The presence of these species may be associated with the dispersion syndrome, since $M$. polymorphum and $V$. discolor have anemochoric syndrome, while $S$. mauritianum has zoochoric syndrome. One factor which may explain the presence of $S$. mauritianum seeds in the area is the occurrence of individuals of this species among eucalyptus, which were observed in loco during data collection.

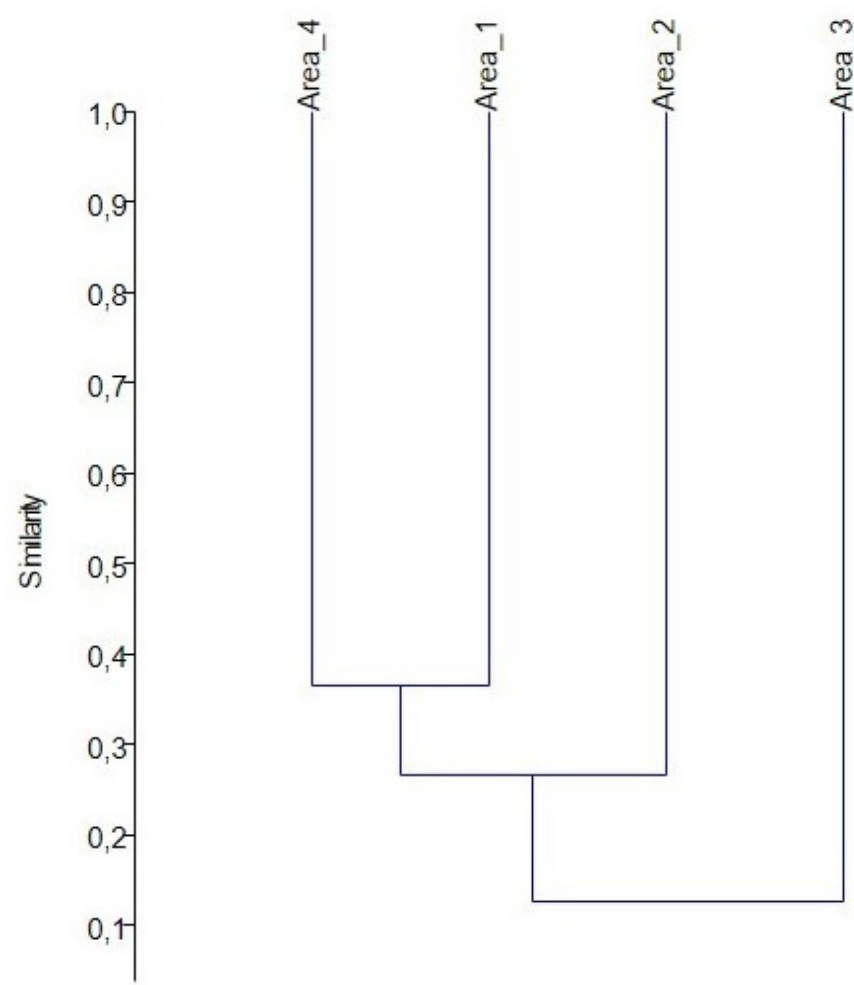

Area 1: planting in nuclei; Area 2: passive restoration area; Area 3: area with eucalyptus plantations; Area 4: native forest.

Figure 3. Floristic similarity dendrogram using the Jaccard index for seed rain in the municipality of Caçapava do Sul, RS, Brazil, in a sample period of 12 months. 


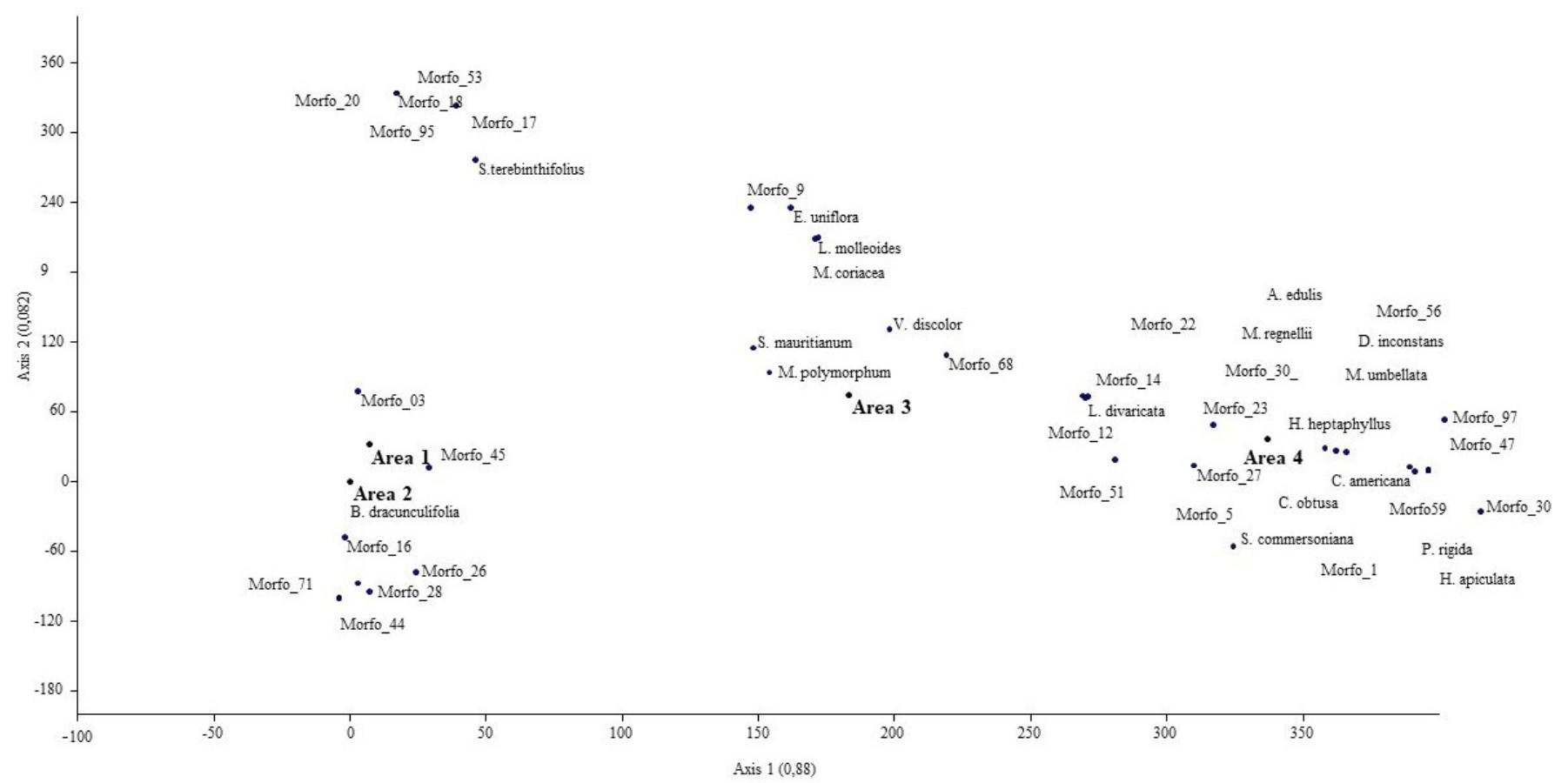

Legend: B. dracunculifolia (Baccharis dracunculifolia DC.); C. americana (Cordia americana (L.) Gottschling \& J.S.Mill); M. umbellata (Myrsine umbellata Mart.); P. rigida (Parapiptadenia rigida (Benth.) Brenan); S. commersoniana (Sebastiania commersoniana (Baill.) L.B. Sm \& Downs); M. regnellii (Mimosa regnellii Benth.); H. apiculata (Helietta apiculata Benth.); S. mauritianum (Solanum mauritianum Scop.); V. discolor (Vernonia discolor (Spreng.) Less.); L. divaricata (Luehea divaricata Mart. \& Zucc); M. polymorphum (Moquiniastrum polymorphum (Less.) G. Sancho); E. deciduum (Erythroxylum deciduum A.St.-Hil.); A. edulis (Allophylus edulis (A.St.-Hil.) Hieron. ex Niederl.); H. heptaphyllus (Handroanthus heptaphyllus (Vell.) Mattos); C. obtusa (Chomelia obtusa Cham. \& Schltdl); S. terebinthifolius (Schinus terebinthifolius Raddi); M. coriacea (Myrsine coriacea (Sw.) R.Br. ex Roem. \& Schult.sp); L. molleoides (Lithraea molleoides (Vell.) Engl.); E. uniflora (Eugenia uniflora L.); D. inconstans (Diospyros inconstans Jacq.).

Figure 4. Ordering diagram of the Detrended Correspondence Analysis (DCA) showing the arrangement of the areas in relation to the morphospecies sampled in the seed rain for a period of 12 months in the municipality of Caçapava do Sul, RS, Brazil. Area 1: planting in nuclei; Area 2: passive restoration area; Area 3: area with eucalyptus plantations; Area 4: native forest.

Area 4 has correlation with a greater species richness when compared to the other areas, and consequently a greater diversity which can be explained because the area is a native forest. Among the species present, we can highlight: Cordia americana; Myrsine umbellata; Parapiptadenia rigida; Sebastiania commersoniana; Mimosa regnellii; Helietta apiculata; Luehea divaricata; Erythroxylum deciduum; Allophylus edulis; Handroanthus heptaphyllus; Chomelia obtusa and Diospyros inconstans. Among these, the zoochoric syndrome species were responsible for $42 \%$ of the number of seeds in the seed rain, the ones with the greatest abundance of seeds were $M$. umbellata, $C$. obtusa and $D$. inconstans, with a predominance pattern of this syndrome in A4.

This greater richness and the predominance of zoochoria reinforce the importance of native forests close to the restoration intervention sites (Souza et al., 2014; Holl et al., 2016). In the study by Holl et al. (2016) in evaluating different restoration strategies and surrounding forest cover, the authors reiterated the importance of conserving native forests for a region's biodiversity. Native forests close to disturbed sites or undergoing the restoration process help in the succession process (Souza et al., 2014).

Area 4 correlated with species attractive to dispersing fauna such as M. umbellata, E. deciduum, A. edulis, C. obtusa and D. inconstans (Sccoti et al., 2016; Capelesso et al., 2018; Guarino et al., 2018) and melliferous species such as $M$. regenellii (Radaeski et al., 2019), which is advantageous to the processes of connectivity and maintenance of forest remnants due to the displacement of fauna (Brandão et al., 2017).

Through the seed rain assessment in the present study, it was possible to verify the species composition, seed availability and diversity in different forest formation soil uses and areas under restoration. Seed rain is a good ecological indicator for monitoring forest restoration. However, it is suggested to select a larger set of ecological indicators and tested locally in order to provide greater support for monitoring restoration areas in the Pampa biome.

\section{Conclusion}

Seed rain is a good indicator to differentiate ecosystem conditions. Active restoration through planting in nuclei is more efficient for the return of seed rain than passive restoration, and the site under passive restoration presents an initial restoration process despite 12 years after isolation.

Commercial eucalyptus planting has little interaction with seed rain, even acting as a barrier to seed dispersal. On the other hand, the native forest acts as a source of resources for the local seed dispersing fauna.

The anemochoric dispersion syndrome predominates in areas which do not yet form the forest canopy. Baccharis dracunculifolia species strongly influences seed rain in the study region. 


\section{Acknowledgements}

The authors would like to thank the CMPC Celulose Riograndense for the financial support and the Coordination for the Improvement of Higher Education Personnel (CAPES) for the Master's scholarship granted to the first author through the Postgraduate Program in Agricultural Engineering at the Federal University of Santa Maria (UFSM).

\section{Literature Cited}

Alvares, C. A.; Stape, J. L.; Sentelhas, P. C.; Gonçalves, J. L. de M.; Sparovek, G. Ko"ppen's climate classification map for Brazil. Meteorologische Zeitschrift, v. 22, n. 6, p. 711-728, 2014. https:// doi.org/10.1127/0941-2948/2013/0507.

Amaral, G. A.; Aita, M. F.; Maldaner, J.; Tarouco, A.K. A produção animal como opção ao controle do capim-annoni e a conservação do Pampa. In: Chomenko, L.; Moura, L. A. (Coords.). RS Biodiversidade. 14.ed. Porto Alegre: Fundação Zoo Botânica, 2016. p.30-33.

Araújo, A. P. A.; Carneiro, M. A. A.; Fernandes, G. W. E. Efeitos do sexo, do vigor e do tamanho da planta hospedeira sobre a distribuição de insetos indutores de galhas em Baccaris pseudomyriocephala Teodoro (Asteraceae). Revista Brasileira de Entomologia, v. 47, n. 4, p. 483-490, 2003. https://doi.org/10.1590/S008556262003000400001.

Boldrini, I.J.; Overbeck, G.O.; Trevisan, R. Biodiversidade de plantas. In: Pillar, V. de. P.; Lange, O. (Coords.). Os Campos do Sul. Porto Alegre: Rede Campos Sulinos; UFRGS, 2015. Chap. 3, p. 33-44.

Bona, K.; Purificação, K.N.; Vieira, T. B.; Mews, H. A. Fine-scale effects of bamboo dominance on seed rain in a rainforest. Forest Ecology and Management, v. 460, article 117906, 2020. https:// doi.org/10.1016/j.foreco.2020.117906.

Brack, P.; Rodrigues, R. S.; Sobral, M.; Leite, S. L. de C. Árvore e arbustos na vegetação natural de Porto Alegre, Rio Grande do Sul, Brasil. Iheringia, Série Botânica, v. 2, n. 51, p.139-166, 1998. https:// www.researchgate.net/publication/268506586. 07 Jan. 2020.

Brandão, J. F. C.; Martins, S. V.; Brandão, I. J.; Lopes, W.P. Ecological Restoration in área dominated by Pteridium aquilinum (L.) Kuhn in Carapaó National Park, MG. Resvista Árvore, v. 41, n. 1, e410104, 2017. https://doi.org/10.1590/1806-90882017000100004.

Budke, J. C.; Athayde, E. A.; Giehl, E. L .H.; Záchia, R. A.; Eisinger, S. M. Composição florística e estratégias de dispersão de espécies lenhosas em uma floresta ribeirinha, arroio Passo das Tropas, Santa Maria, RS, Brasil. Iheringia, Série Botânica, v.60, p.17-24, 2005. https://isb.emnuvens.com.br/iheringia/article/ view/202/209. 13 Apr. 2020.

Campos, E, P.; Vieira, M. F.; Silva, A. F.; Martins, S. V.; Carmo, F. M.; Moura, V.M.; Ribeiro, A. S. S. Chuva de sementes em floresta estacional semi decidual em Viçosa, MG, Brasil. Acta Botanica Brasilica, v.3, n.2, p. 134-154, 2009. https://doi.org/10.1590/ S0102-33062009000200017.

Capellesso, E. S.; Scrovonski, K. L.; Zanin, E. M.; Sausen, T. S. Relação entre chuva de sementes e estrutura florestal em remanescente de floresta atlântica no sul do Brasil. Iheringia, Série Botânica, v.73, n.2, p.176-181, 2018. https://doi.org/10.21826/24468231201873209 .
Durigan, G. O uso de indicadores para monitoramento de áreas em recuperação. Cadernos da Mata Ciliar, v.4, p.11-13, 2011. https://sigam.ambiente.sp.gov.br/sigam3/Repositorio/222/ Documentos/Cadernos_Mata_Ciliar_4_Monitoramento.pdf. 29 Mar. 2020.

Durigan, G.; Engel, V. L. Restauração de ecossistemas no Brasil: onde estamos e para onde podemos ir? In: Martins, S. V. (Ed.). Restauração ecológica de ecossistemas degradados. 2.ed. Viçosa: Editora da UFV, 2015. Cap. 2, p.41-68.

Echer, R.; Cruz, J. A. W. Da.; Estrela, C. C.; Moreira, M.; Gravato, F. Usos da terra e ameaças para a conservação da biodiversidade no bioma Pampa, Rio Grande do Sul. Revista Thema, v. 12, n. 2, p. 4-12, 2015. https://doi.org/10.15536/thema.12.2015.4-13.318.

Fagundes, M.; Neves, F. S.; Fernandes, G. W. Direct and indirect interactions involving ants, insect herbivores, parasitoids, and the host plant Baccharis dracunculifolia (Asteraceae). Ecological Entomology v. 30, n.1, p. 28-35, 2005. https://doi.org/10.1111/ j.0307-6946.2005.00668.x

Felker, R. M.; Rovedder, A. P. M.; Longhi, S. J.; Araújo, E. F.; Stefanelo, M. M.; Júnior, J. C. C. S.; Procknow, D.; Hummel, R. B.; Piaia, B, B.; Camargo, B.; Leal da Silva, M, P. K.; Toso, L. D. Regeneração natural em área sob domínio de bambu, no sul do Brasil. Revista de Ciências Agrárias, v. 41, n. 1, p.82-92, 2018. http://dx.doi. org/10.19084/RCA17100.

Giehl, E. L. H.; Athayde, E. A.; Budke, J. C.; Gesing, J. P. A.; Eisinger, S. M.; Canto - Dorow, T. S. Espectro e distribuição vertical das estratégias de dispersão de diásporos do componente arbóreo em uma Floresta Estacional no sul do Brasil. Acta Botanica Brasilica, v.21, n.1, p.137-145, 2007. https://doi.org/10.1590/ S0102-33062007000100013.

Gomes, V.; Fernandes, G. W. Germinação de aquênios de Baccharis dracunculifolia D. C. (Asteraceae). Acta Botanica Brasilica, v. 16, n.4, p. 421-427, 2002. https://doi.org/10.1590/S010233062002000400005.

Guarino, E. S. G.; Overbeck, G. E.; Boldrini, I. I.; Muller, S. C.; Rovedder, A. P.; Freitas, T. C.; Gomes, G. C.; Noronha, A. H.; Miura, A. K.; Sousa, L. P.; Sant'anna, D. M.; Chomenko, L.; Molz, M.; Mahler Júnior, J. K. F.; Molina, A. R.; Espindola, V. S. Espécies de plantas prioritárias para projetos de restauração ecológica em diferentes formações vegetais no Bioma Pampa: primeira aproximação. Pelotas: Embrapa Clima Temperado, 2018. 79 p. (Embrapa Clima Temperado. Documentos, 457). http://ainfo.cnptia.embrapa.br/ digital/bitstream/item/185121/1/DOCUMENTO-457-Ernestinode-Souza-Guarino.pdf. 29 Mar. 2020.

Hammer, O.; Harper, D. A.; Ryan, P. D. PAST -Paleontological Statistics. Versão 2.17, 2004. http://www.folk.uio.no/ohammer/past. 20. Oct. 2019.

Holl, K. D.; Reid, J. L.; Chaves-Fallas, J. M.; Oviedo-Brenes, F.; Zahawi, R. A. Local tropical forest restoration strategies affect tree recruitment more strongly than does landscape forest cover. Journal of Applied Ecology, v. 54, n. 4, p.1091-1099, 2016. https:// doi.org/10.1111/1365-2664.12814.

Hutcheson, K. A test for comparing diversities based on the Shannon formula. Journal of Theoretical Biology. v. 29, n.1, p. 151-154, 1970. https://doi.org/10.1016/0022-5193(70)90124-4. 
Kanieski, M. R.; Longhi, S. J.; Araújo, A. C. B. Quantificação da biodiversidade em Floresta Ombrófila Mista por meio de diferentes índices Alfa. Scientia Forestalis, v. 38, n. 88, 2010. https://www. ipef.br/publicacoes/scientia/nr88/cap03.pdf. 04 Jun. 2019.

Kanieski, M. R.; Longhi, S. J.; Milani, J. E. De F.; Santos, T. L.; Soares, P. R. C. Caracterização florística e diversidade na florestal nacional de São Francisco de Paula, RS, Brasil. Floresta, v. 47, n. 2, p. 177 185, 2017. https://doi.org/10.5380/rf.v47i1.44585.

Magurran, A. E. Medindo a diversidade biológica. Curitiba: Editora UFPR, 2013. 261p.

Marchi, M. M.; Barbieri, R. L.; Sallés, J. M.; Costa, F. A. da. Flora herbácea e subarbustiva associada a um ecossistema de butiazal no Bioma Pampa. Rodriguésia, v. 69, n. 2, p. 553-560, 2018. https://doi.org/10.1590/2175-7860201869221.

Marchiori, J.N.C. Fitogeografia do Rio Grande do Sul. Embasamento florístico. Porto Alegre: EST, 2006. 40 p.

Marsden, S. J.; Whiffin, M.; Galetti, M. Bird diversity and abundance in forest fragments and Eucalyptus plantations around an Atlantic forest reserve, Brazil. Biodiversity and Conservation, v. 10, p. 737751, 2001. https://doi.org/10.1023/A:1016669118956.

Müeller-Dombois, D.; Ellenberg, H. Aims and methods of vegetation ecology. New York: John Wiley \& Sons, 1974. 547p.

Huanca Nuñez, N.; Chazdon, R. L.; Russo, S. E. Determinism and stochasticity in seed dispersal-successional feedbacks. BioRxiv, v. 79, e7919882019, 2019. https://doi.org/10.1101/791988.

Overbeck, G. E.; Boldrini, I. I.; Carmo, M. R. B. Do.; Garcia, É. N.; Moro, R. S.; Pinto, C. E.; Trevisan, R. Zannin, A. Fisionomia dos campos. In: Pillar, V. De. P.; Lange, O (Coords.). Os campos do Sul. Porto Alegre: Rede Campos Sulinos; UFRGS, 2015. Chap. 3, p. 33-44.

Pillar, V. De. P.; Müller, S. C.; Castilhos, Z. M. de. S.; Jacques, A. V. Á. Campos Sulinos: conservação e uso sustentável da biodiversidade. ed. Brasília: MMA, 2009. 403 p. https:// www.mma.gov.br/publicacoes/biomas/category/64-pampa. html?download=1060: campos-sulinos-conservacao-e-usosustentavel-da-biodiversidade. 09 Apr. 2020.

Pinã-Rodrigues, F. C. M.; Aoki, J. Chuva de sementes como indicadora do estádio de conservação de fragmentos florestais em SorocabaSP. Ciência Florestal, v. 24, n. 4, p. 911-923, 2014. https://doi. org/10.1590/1980-509820142404011.

Radaeski, J. N.; Silva, C. I.; Bauermann, S. G. Melissopalinologia no Rio Grande do Sul: revisão e caracterização das espécies botânicas potenciais à apicultura e meliponicultura. Acta Biológica Catarinense, v.6, n.2, p. 63-75, 2019. https://doi.org/10.21726/abc.v6i2.698.

Rech, C. C. C.; Silva, A. C. Da.; Higuchi, P.; Schimalski, M. B.; Pscheidt, F.; Schmidt, A. B.; Ansolin, R. D.; Bento, M. A.; Missio, F. de F.; Loebens, R. Avaliação da Restauração Florestal de uma APP Degradada em Santa Catarina. Floresta e Ambiente, v.22, n.2, p.194-203, 2015. https://doi.org/10.1590/2179-8087.083414.

Rovedder, A. P. M. Bioma Pampa: relações solo-vegetação e experiências de restauração. In: Congresso Nacional de Botânica, 64., 2013, Belo Horizonte. Anais... Belo Horizonte: Sociedade Botânica do Brasil, 2013. p. 46-53.
Rovedder, A. P.; Overbeck, G.; Pillar, V.; Matsumoto, M; Braga, J.V. Potencial de regeneração natural da vegetação no Pampa. In: MMA; WRI (Eds.). Potencial da regeneração natural da vegetação no Brasil. Brasília: Ministério do Meio Ambiente, 2017. p.2-9. https://www.researchgate.net/publication/325581059. 30 Mar. 2019.

Sccoti, M. S. V.; Araújo, M. M.; Tonetto, T. S.; Longhi, S. J. Dinâmica da chuva de sementes em remanescente de floresta estacional subtropical. Ciência Florestal, v. 26, n. 4, p. 1179-1188, 2016. https://doi.org/10.5902/1980509825109.

Scipioni, M. C.; Galvão, F.; Longhi, S. J. Composição florística e estratégias de dispersão e regeneração de grupos florísticos em florestas estacionais deciduais no Rio Grande do Sul. Floresta, v. 43, n.2, p.241-254, 2013. https://doi.org/10.5380/ rf.v43i2.27098.

Souza, J. T.; Ferraz, E. M. N.; Albuquerque, U. P.; Araújo, E. L. Does proximity to a mature forest contribute to the seed rain and recovery of an abandoned agriculture área in a semiarid climate. Plant Biology, v. 16, n.4, p. 748-756, 2014. https://doi. org/10.1111/plb.12120.

Souza, S. C. P. M. De S.; Gandolfi, S.; Rodrigues, R. R. A influência da cobertura vegetal e da distância do remanescente florestal no processo de regeneração natural na Floresta Ombrófila Densa Montana. Hoehnea, v. 45, n.1, p. 55-68, 2018. https://doi. org/10.1590/2236-8906-20/2017.

Streck, E.V.; Kampf, N.; Dalmolin, R, S, D. Solos do Rio Grande do Sul. 2.ed. Porto Alegre: Emater RS, 2008. 222 p.

Tres, D. R; Santa'anna, C. S.; Basso, S.; Langa, R.; Ribas, U.; Reis, A. Banco e chuva de sementes como indicadores para a restauração ecológica de matas ciliares. Revista Brasileira de Biociências, v. 5 , n. 1, supl. 1, p. 309-311, 2007. http://www.ufrgs.br/seerbio/ojs/ index.php/rbb/article/viewFile/331/289. 18 Nov. 2019.

Van Der Pijl. Principles of dispersal in higher plants. 3. ed. New York: Springer-Verlag, 1982. $214 \mathrm{p}$

Venzke, T. S.; Martins, S. V.; Neri, A. V.; Kunz, S. H. Síndromes de dispersão de sementes em estágios sucessionais de mata ciliar, no extremo sul da Mata Atlântica Arroio do Padre, RS, Brasil. Revista Árvore, v.38, n.3, p.403-413, 2014. https://doi.org/10.1590/ S0100-67622014000300002.

Vinha, D.; Alves, L. F.; Zaidan, L. B. P.; Grombone-Guaratini, M. T. Influence of Aulonemia aristulata (Bambuseae) overabundance on the transient seed bank of an Atlantic Forest fragment. Rodriguésia, v. 68, n. 4, p.1177-1186, 2017. https://doi. org/10.1590/2175-7860201768402.

Wang, Y.; LaMontagne, J. M.; Lin, F.; Yuan, Z.; Ye, J.; Wang, X.; Hao, $Z$. Similarity between seed rain and neighbouring mature tree communities in an old-growth temperate forest. Journal of Forestry Research, 2019. https://doi.org/10.1007/s11676-01901027-3. 